\title{
FEDERAL REGULATION OF COMMODITY FUTURES TRADING
}

RECENT demands for increased federal restriction of commodity speculation have focused widespread attention on organized commodity exchange trading. ${ }^{1}$ Prompted chiefly by price increases following the outbreak of the Korean $\mathrm{War}^{2}$ this latest burst of criticism adheres to a historically familiar stereotype-the belief that speculation leads to agricultural price depressions and inflations. ${ }^{3}$

1. President Truman has been one of the most persistent exponents of tighter federal regulation of commodity speculation. In his April 26, 1951, message to Congress requesting extension of the Defense Production Act of 1950, the President recommended that a provision be added authorizing federal "control of margins for speculation on" commodity futures markets." N.Y. Times, April 27, 1951, p. 10, col. 5. For a discussion of futures margin regulation, see pages $844-47$ infra.

The bill which became the Defense Production Act of 1950 originally contained a similar provision. H.R. 9176, § 411, 96 Cong. Rec. 12408 (Aug. 10, 1950). This section was, however, deleted by both houses before final passage of the Act. A substitute provision, $\$ 606$, requiring exchanges to limit "excessive" speculation upon advice from the Secretary of Agriculture met a similar fate.

Numerous earlier bills providing for federal authority to set futures trading margins also failed to pass. The most recent of these are H.R. 4685, introduced in the 81 st Cong., 1st sess., on May 16, 1949, by Rep. Cooley, and H.R. 2624, introduced by Rep. Walsh on Feb. 10, 1949.

The President has reiterated his requests for federal power to restrict futures speculation in most of his recent economic reports. See, e.g., Jan. 12, 1951, Economic Message to Congress, N.Y. Times, Jan. 13, 1951, p. 5, col. 4; 1950 Mid-year Economic Report to Congress, N.Y. Times, July 27, 1950, p. 18, col. 5. See also July 19, 1950 message to Congress on the Korean situation, N.Y. Times, July 20, 1950, p. 14, col. 8, and radio address of the same day, id. at p. 15, col. 5.

A similar recommendation was made by Secretary of Agriculture Brannan in an address at Michigan State College on Aug. 22, 1950. N.Y. Times, Aug. 25, 1950, p. 43, col. 7. See note 2 infra. See also Rep. Comarodity Exchange Authority [hereinafter designated as CEA] 7-11 (1950).

2. In his radio address of July 19, 1950, President Truman said: "[W] must adopt measures to prevent inflation and to keep our Government in a sound financial condition. One of the major causes of inflation is the excessive use of credit. I have [therefore] recommended that the Congress authorize the Government to . . . curb speculation in agricultural commodities." N.Y. Times, July 20, 1950, p. 15, col. 5 . And on Dec. 24, 1950, Senator Humphrey called on the newly elected 82d Congress to give the President "full authority to crack down on" commodity speculation, which, the Senator contended, was adding billions of dollars to the cost of the defense program. N.Y. Times, Dec. 25, 1950, p. 17, col. 6 .

3. Baer \& Saxon, Comsmodity Exchanges and Futures Trading 55 (1949). The recurring strength of this sentiment is demonstrated by the fact that most of the early congressional bills dealing with commodity futures trading were introduced during periods of agricultural depression. See Hofrman, Future Trading Upon Organized Commodity Markets in the United States $365-7$ (1932).

In addition, futures speculation has long been attacked as a form of gambling. Id. at 353-4. For a strong exposition of this position, see E. D. MacDougall, Speculation and 
This belief has some validity, though not as much as the victims of such economic disequilibria have claimed. ${ }^{4}$ Federal regulation, with its gradually tightening curbs on speculation, has considerably reduced these disturbances. And certain modifications of the basic regulatory statute, the Commodity Exchange Act, ${ }^{5}$ would operate to decrease still further the magnitude and frequency of price movements induced solely by speculative market activity. Improved means of attaining this objective must, however, be designed so as not to hamper the useful functions which commodity exchange trading serves in the marketing of agricultural and other commodities.

\section{Functions of Speculation on Commodity Exchanges}

Transactions on organized commodity exchanges involve primarily ${ }^{6}$ the purchase and sale of "futures" " - contracts for the delivery of a specified

Ganrblrng c. 6 (1936). This attitude is reflected to a great extent in state law dealing with futures contracts. See note 40 infra. The defense of futures speculation against the charge of gambling is based primarily on the social and economic utility of the former. BAER \& SAXON, op. cit. supra, at 58-63.

4. For an anaylsis of price distortions brought about by speculation, see 7 FTC, REP. ON THE GRAIN TRADE c. 7 (1926). The influence of large-scale speculators on price movements in the early years of federal regulation is extensively analyzed in Hoffman, Grain Prices and the Futures Market: A 15-Year Survey, 1923-1938 41-60 (Dep't Agric. Tech. Bull. No. 747, 1941) [hereinafter cited as Hofrsran, SuRvey (1941)]. See also CEA, Twenty-Five Years of Futures Trading under FederaI REGULATION 5, 9-10 (1950); Irwin, The Nature of Risk Asstmtption in the Trading on Organized Exchanges, 27 Aar. Econ. Rev. 267-78 (1937).

5. 42 STAT. 998 (1922), as amended, 49 Stat. 1491 (1936), 7 U.S.C. $\$ 1$ (1946).

6. Most exchanges provide facilities only for futures trading, although on some, particularly the grain exchanges, dealings in both cash and futures contracts are conducted. Baer \& Saxon, Comirodity Exchanges and Futures Trading 29 (1949).

7. Futures contracts typically contain the following features:

(1) A standard unit of trading. The unit for wheat, corn, and other grain futures contracts is 5,000 bushels. In addition to this standard "round lot," the leading grain exchanges also provide a "job lot" of 1,000 bushels for the convenience of smaller traders. The unit for cotton is " 50,000 pounds in about 100 square bales." Hofrman, Future Trading Upon Organized Commodity Markets in the United States 101 (1932). For the contract units of other commodities subject to federal regulation, see REP. CEA 9 (1950).

(2) Several deliverable grades. The seller may, at his option, deliver on his contract any one of several deliverable grades of a given commodity.

(3) Price based on "basis" grade. Price quotations on the exchanges are for a socalled "basis grade." If the seller chooses to deliver a grade other than the basis grade, the quoted price will be adjusted by a premium or discount depending on whether the grade tendered is better or poorer than the basis grade.

(4) Delivery during a specified month. Delivery may be made, at the seller's option, on any day of the delivery month. The delivery period may be extended by the Secretary of Agriculture for not more than ten days after cessation of trading in the particular future. See note 91 infra. Delivery months for grain futures are May, July, September, and December; see 5 FTC, Rep. on the Grain Trade 62 (1920). 
quantity of a certain commodity ${ }^{8}$ in a given future month. Most of these futures commitments are offset, by the sale of futures equalling the number previously purchased or vice versa, before the arrival of the delivery month. ${ }^{9}$

(5) Delivery by transfer of warehouse receipt. Delivery on futures contracts is effected by delivery to the buyer of the warehouse receipts for the commodity. The commodity must be stored in an approved warehouse.

For further discussion of the characteristics of futures contracts, see BAER \& SAXON, Commodity Exchanges and Futures Trading c. 7 (1949); Hoffman, Future Trading Upon Organized Comarodity Markets in the UnIted States c. 6 (1932).

The fact of forward delivery does not itself distinguish futures contracts from contracts on the physical market, generally known as the cash or spot market, which may take the form of "to arrive" contracts providing for deferred delivery. Futures tading differs from dealings in the physical market in that the latter contemplate delivery of a specific lot and grade of some commodity, usually on a definite date. Hofrman, Future Trading Upon Organized Conrarodity Markets in the United States 104-110 (1932).

The historical development of American futures trading in the major commodities is extensively described in HofrMaN, op. cit. supra, cc. 2 and 3.

8. The commadities in which futures trading is conducted are listed in note 66 infra.

In the fiscal year 1950, soybeans, wheat, cotton, and corn futures transactions accounted for approximately $90 \%$ of the dollar value of all trading in commodities subject to federal regulation. See note 66 infra. The following table, condensed from Rep. CEA 22 (1950), indicates the relative importance of futures trading in these commodities:

Estimated Value of Futures Trading

\begin{tabular}{|c|c|c|c|}
\hline \multirow{2}{*}{ Oommodity } & \multicolumn{3}{|c|}{ Fiscal Years } \\
\hline & 1948 & 1949 & 1950 \\
\hline & 1,000 dollars & 1,000 dollars & 1,000 dollars \\
\hline Soybeans .... & 147,796 & $3,997,924$ & $9,251,599$ \\
\hline Wheat $\ldots \ldots \ldots \ldots \ldots \ldots \ldots \ldots$ & $14,979,719$ & $10,117,875$ & $9,038,425$ \\
\hline Cotton $\ldots \ldots \ldots \ldots \ldots \ldots \ldots$ & $19,280,146$ & $10,239,847$ & $8,276,064$ \\
\hline Corn $\ldots \ldots \ldots \ldots \ldots \ldots \ldots \ldots$ & $9,166,415$ & $5,723,401$ & $2,736,211$ \\
\hline All others ... & $5,878,077$ & $3,366,465$ & $3,049,146$ \\
\hline Total ... & $49,452,153$ & $33,445,512$ & $32,351,445$ \\
\hline
\end{tabular}

"Not every agricultural commodity is suitable for futures trading. There are sis: special qualifications which determine the fitness of a commodity to be the basis for futures trading. A commodity must be homogeneous, more or less similar throughout; it must be susceptible of grading; it must be sufficiently durable to last throughout the life of a future (ordinarily about 1 year); trading must be in sufficiently large volume to support the cost of facilities required; the market must not be controlled by a few large operators; and the market must be sufficiently wide to be utilized by more than regional interests." Rep. Commodity Exchange Adninistration [hereinafter cited Rep. CE ADMrrN.] 4 (1937). For a more detailed exposition of these reqiurements, see BAER \& Saxon, Comarodity Exchanges and Futures Trading c. 6 (1949).

9. Irwin, Legal Status of Trading in Futures, 32 Ir.. L. REv. 155, 156-7 (1937).

"It is evident that if a man has made both a contract to buy and a contract to sell, in equal amounts, in the same future, and through the same commission house, it would 
In the case of grain futures, which account for the bulk of exchange transactions, ${ }^{10}$ delivery is actually made on less than $1 \%$ of the transactions effected. ${ }^{11}$ Thus trading in futures does not serve primarily to transfer possession of the contract subject matter; rather it involves mainly the assumption of the risk of price change by speculation, ${ }^{12}$ or the shifting of such risk by hedging. ${ }^{13}$

\section{Hedge Facilitation}

Hedging is a device by which commodity dealers and processors protect themselves against adverse price movements in the so-called physical or "cash" market. These movements may be either price declines on cash commodities which they have purchased or contracted to purchase, or price increases on commodities whose sale, generally in processed form, has been contracted for before the raw commodity is actually acquired. ${ }^{14}$ Hedging is

be possible to wait until the grain should be delivered to him on the contract to buy and then apply it on the contract to sell, but there would be no object in such a procedure. Consequently, the man is considered as being 'out of the market' when he makes an offsetting contract." Id. at $157 \mathrm{n} .8$.

10. See note 8 supra.

11. Shepherd, Marketing Farm Products 117 (1946); Hoffman, Survey 24 (1941).

12. "Speculators as a group can be classified in a number of ways. Classified by function they may be (1) open speculators or (2) spreaders, the latter type being those who follow the practice of setting up equal and opposite futures positions between two futures in the same or different markets with the object of profiting from relative price changes. Open speculators, in contrast, assume either a long or short position in futures, but not both, for a possible profit. Open speculators in turn may be professionals, such as floor traders or scalpers attempting to profit from small intraday price changes or traders carrying open positions for periods of time longer than one day, or they may be nonprofessionals-those whose principal occupation lies elsewhere but who trade in futures from time to time." Hofraran, SuRvey 31-32 (1941).

For an interesting, though brief, discussion of spreading (also known as arbitraging) in grain futures, see Harris, Arbitraging in Grain, 155 AwNals 74 (1931). In the cotton trade the term "straddling" is used as the equivalent of spreading in grain.

The various types of speculators-as distinguished from hedgers-are succinctly described in Hoffran, Future Trading Upon Organized Commodity Markets in the United States 135-42 (1932).

13. Rep. CE Admin. 4 (1937); Hofrman, Survey 31 (1941).

On hedging generally, see BaEr \& Saxon, Commodity Exchanges and Futures Trading cc. 11 and 12 (1949) ; 7 FTC, Rep. on the Grain Trade c. 2 (1926); Hoffman, Hedging by Dealing in Grain Futures (1925) passim.

14. Providing facilities for hedging is the principal function of the commodity exchange. Baer \& Saxon, Comarodity Exchanges and Futures Trading 197 (1949). In the grain trade, hedging is carried on chiefly by elevator owners, millers, and exporters. Elevators located at terminal markets hedge with a high degree of consistency, particularly in the spring wheat territory of the Northwest. Except in this area, however, country elevators do not generally engage in hedging. 7 FTC, REP. ON THE GRAIN TRADE 3 (1926) ; Hoffman, The Hedging of Graith, 155 Annals 7, 9-10 (1931). Very 
effected by executing a transaction in futures of equal magnitude but in the opposite position from that held in the cash market.15 Thus, for example, a grain elevator operator buying 5,000 bushels of wheat in July for storage would at the same time undertake, by the short sale ${ }^{16}$ of a December futures contract, to deliver 5,000 bushels of wheat in December. When the stored grain is sold, say in November, the operator would buy a December wheat futures contract for 5,000 bushels. He thereby eliminates his position in the futures market, since his December obligations both to buy and sell 5,000 bushels exactly offset each other. As price movements of futures generally parallel those of the cash commodity, ${ }^{17}$ any loss incurred in the cash market

little hedging is done by farmers. Id. at 9. See also ShepHerd, Marketing Farm Products 112-114 (1946).

Broadly speaking, producers, elevator owners and dealers own stocks of actual commodities before undertaking their sale. These interests thus hedge to protect themselves against price declines in the commodity from the time of acquisition to that of sale. On the other hand, processors and manufacturers, such as millers, often contract for the sale of the commodity or its product before actually obtaining stocks of the commodity. Consequently they employ hedging as insurance against a rise in the price of goods which must be obtained to meet their obligations. BAER \& SAXoN, Commodity EXchanges AND FUtURES TrAdiNG 205 (1949); 7 FTC, op. cit. supra at 34; Hoffman, op. cit. supra at $9-10$.

The failure of some dealers and processors to hedge all or part of their cash commitments may be explained partly by a desire to speculate and partly by the fact that some commodity commitments are not suitable for hedging. The latter is frequently true, for example, of products of commodities whose market values are only loosely related to the price of the original commodity. See note 17 infra. Effective hedging may also be precluded if the commodity is located far outside the main channels of shipment, or if too small a quantity of the commodity is involved. HoFFArar, SURVEY 42 n.21 (1941).

15. The process of hedging in futures in exactly the same quantity and at the same time as the cash transaction is known as "strict-rule hedging." In practice, however, hedgers occasionally deviate from the "strict rule," both as to quantity and timing. 7 FTC, Rep. on the Grain Trade 53-7 (1926).

16. A "short" sale on the futures market is the sale of a futures contract which is not offset by a prior futures purchasing commitment.

17. Baer \& Saxon, Comarodity Exchanges and Futures Trading 206 (1949). The reasons for this relationship, together with an analysis thereof in four commodities for a ten-year period, are set out in Hofrman, Future Trading Upon Organized Commodity Markets in the United States 254-60 (1932). See also Hoffman, SURVEY 28-30 (1941).

Despite the over-all tendency of futures and cash prices to move together, a number of factors may interfere with this relationship and thus preclude perfect protection through hedging. Such disturbances may occur both in the spread between the market price of the cash commodity and the various futures, see Stevens, Relationship of Cash and Futures Prices, 155 AnNals 79 (1931), and in the relationship between the price of the basis grade and the various other grades dealt with in the physical market. BAER \& Woodruff, Comarodtry Exchanges 89 (1935).

An additional complication is introduced in the case of processor hedging. Here successful hedging requires that price movements of the manufactured product parallel those of the raw commodity. Whether this relationship exists depends to a large extent 
would be compensated for by a corresponding gain on the futures transaction. 18

Hedging is advantageous to producer, consumer, and middleman. The middleman can operate on less capital than would be required in the absence of hedging, because of the insurance against adverse price changes and the resulting improved credit position which hedging provides. ${ }^{10}$ Consumers and producers benefit from the fact that cutting the risk of loss due to adverse price changes reduces the middleman's operating costs, and thus tends to decrease the gap between the amounts paid by the consumer and received by the producer for the commodity. ${ }^{20}$

However, extensive hedging activities on exchanges are made possible only by the presence of speculators-persons whose futures transactions are not designed to protect a cash market position ${ }^{21}$ - willing to assume the risks which hedgers seek to shed. "Short" hedgers, such as grain elevator operators who initially sell futures to protect their cash commodities against price declines, account for a far larger number of futures contracts than "long" or buying hedgers, such as processors who sell their products before purchasing the raw commodity. ${ }^{22}$ Speculators are therefore needed in order to equalize the number of futures sold and bought. Furthermore, there must be sufficient

on the proportion which the raw material cost bears to that of the finished product. BAER \& WoOdRUFF, op. cit. supra, at 91 . For graphs showing the correlation of flour prices and wheat costs, see Moore, Hedging by a Wheat Flour Miller in ProceEdings, 3D Annual Grain Marketing Symposium 63-4 (Chicago Board of Trade, 1950).

In addition to the vicissitudes in the future-cash price relationship a further fact which prevents the hedger from breaking exactly even is the brokerage commission which he must pay on his futures hedging transactions. In grain futures this amounts to $x / 4$ cent per bushel for the "round turn," i.e., the sale and purchase together. SHEPHERD, Marketing Farm Products 107 (1946).

18. Of course, successful hedging also "insures" against possible profits from cash market price changes. But the hedger is willing to forgo this gain for the protection which hedging provides in case of adverse price changes. He is interested in profits derived from handling or processing the actual commodity, not in speculative profits. See Baer \& Saxon, Comarodity Exchanges and Futures Trading 204 (1949).

19. Banks lending to commodity interests strongly encourage hedging and extend credit to a higher percentage of the value of goods pledged as security if they have been hedged. Bafr \& Saxon, Commodity Exchanges and Futures Trading 212 (1949).

20. Baer \& Saxon, Commodity Exchanges and Futures Trading 34-7, 213 (1949); Hearings before Committee on Agriculture and Forestry on S. 1881, 80th Cong., 2d Sess. 29, 143-8, 151 (1948).

It has been suggested that hedging results in lower trade margins primarily because it permits the entrance into the commodity trade of smaller dealers with comparatively little capital, thus resulting in broader and more effective competition. 7 FTC, REP. ow THE Grain Trade 37, 239-41 (1926).

21. See note 12 supra.

22. Rep. CEA 26-7 (1950); Hoffaran, SuRvey 36-9 (1941).

But cf. the unusual situation in May, 1946, when speculators in wheat and corn were net short while hedgers held a net long position. CEA, EFFECT oN FuturEs TRADING IN Grains of Changes in Price Ceitungs of May 13, 1946 (1946). 
futures market liquidity, in the sense of a large enough volume of trading, to accommodate a hedging transaction whenever the need for one arises. This requires a sizable number of speculative trades, both on the long and short sides. ${ }^{23}$

\section{Price Stabilization}

Futures speculation also has a role ${ }^{24}$ in stabilizing commodity prices. ${ }^{25}$ Both comparative analysis of particular commodities ${ }^{26}$ and German ${ }^{27}$ and American ${ }^{28}$ experience under temporary suspension of futures trading in-

23. See Baer \& Saxon, Commodity Exchanges and Futures Trading 32, 34, 73-5 (1949). For a discussion of the volume of speculation necessary adequately to support hedging, see pages 847-48 infra.

24. The two functions of commodity futures trading discussed here-hedge facilitation and price stabilization-are those most relevant to the problem of governmental regulation of exchange transactions. Other functions include providing a continuous year-round market for the commodities in which trading is conducted, and aiding efficient price determination by providing systematic daily price quotations. REP. CE ADMIN. 4 (1937).

25. See, generally, Frederick, Agricultural Markets 59-60 (1937); 7 FTC, Rep. on the Grain Trade 16-18 (1926); Brace, The Value of Organized Speculation 54-9 (1913). In Board of Trade of the City of Chicago v. Clyne, 260 U.S. 704 (1922), involving the constitutionality of the Grain Futures Act, twenty-two prominent economists filed affidavits in which each "declared his belief that, with infrequent and minor exceptions, futures trading had a marked tendency to stabilize prices." BAER \& SAXON, CoMmodrty Exchanges and Futures Trading 69 n.10 (1949).

26. Probably the most reliable of these studies compared the Chicago Board of Trade prices of wheat, oats, and barley, the last of which was not the subject of futures trading, for the period 1899-1916. Whereas wheat prices showed a fluctuation of over 100\% in only one of these years, and oats in two, barley prices fluctuated by at least this amount in eight of the 18 years analyzed. Boyle, Speculation and the Chicago Board of Trade 122-3 (1920). A similar comparison, though of more doubtful validity, was made by the Minneapolis Chamber of Commerce between price fluctuations of wheat and those of onions, potatoes, and apples over a 29 -year period. No futures trading was then conducted in the latter three commodities. This study revealed an average annual fluctuation in wheat prices of only $5.36 \%$; on the other hand, onions fluctuated more than $10.9 \%$, apples almost $100 \%$, and potatoes $68 \%$. Futures transactions are now conducted in all these commodities. See note 66 infra. Baer \& Saxon, Connsodity Exchanges and Futures Trading 71 (1949).

27. The German Exchange Act of 1896 prohibited all exchange dealings for future delivery in grain and flour. Emery, Ten Years Regulation of the Stock Exchange in Germany, 17 Y YLE REv. 5, 8 (1908). As a result of this measure, directed against short selling, bull movements and reactions were accentuated. BAER \& WOODRUFF, CoMnodiTy Exchanges 185 (1935). For further discussion of the bizarre effects of the German Exchange Act on futures trading practice, see Emery, The Results of the German Exchange Act of 1896, 13 PoL. Scr. Q. 286, 291-301 (1908). See also Boyle, Speculation and the Chicago Board of Trade 182-96 (1920).

28. Futures trading in wheat was suspended because of the World War I emergency in August 1917. Menc, The Future of the Futures Markets 12 (1941). As a result, "[f]luctuations in cash wheat [prices] became violent and there were many days when spot wheat declined or advanced 25 to 30 cents a bushel." Uhlman Grain Co. Letter to the 
dicate that a greater element of price stability may be expected when speculative trading exists than in its absence.

The traditional theoretical explanation of this phenomenon is that speculators actively acquaint themselves with the factors likely to affect prices, and, by acting on this information, bring about gradual price changes reflecting future cash commodity conditions. ${ }^{29}$ The reduction of unusual and unnecessary price fluctuations thus depends on the speculators' capacity to divine future price influences. ${ }^{30}$

Actually, however, most speculators are not experts. A large percentage are engaged in occupations totally unrelated to the marketing of commodities. ${ }^{31}$ Moreover, most speculators carry relatively small accounts ${ }^{32}$ and the vast majority do not engage in speculation as a full-time business. ${ }^{33}$ These facts cast doubt on most traders' familiarity with underlying price factors. And a study of grain futures trading for the period 1923-38 indicates that the large speculator possesses only slightly greater omniscience than the average speculator. Although the combined trading of a group of large speculators was found to parallel price changes, the activities of the individual large traders deviated considerably from the general price pattern. ${ }^{34}$

The price stabilizing influence of speculation is actually best viewed in terms of the pattern of trading habits characteristic of large and small speculators

Trade quoted in N.Y. Times, Aug. 25, 1950, p. 29, col. 2. See also Boyle, SpEculation and the Chicago Board of Trade 124 (1920).

29. Frederick, Agricultural Markets 59-60 (1937). Baer \& Woodruff, Commodity Exchanges 22-3 (1935); Irwin, The Nature of Risk Asstmption in the Trading on Organized Exchanges, 27 AMr. ECoN. Rev. 267 (1937).

30. Hoffman, Past and Present Theory Regarding Futures Trading, 19 J. FARM Econ. 300, 308 (1937).

31. Analysis by the Department of Agriculture of Chicago Board of Trade wheat and corn futures commitments open on September 29,1934, revealed that speculators were engaged in approximately 600 occupations and subdivisions ranging alphabetically from abstractors to yeast makers. Clerks, merchants (including automobile dealers, druggists, grocers, etc.) and related professional groups held $52 \%$ of the total number of speculative accounts. Executives, financiers, and professionals accounted for an additional $26 \%$ of the total. Although farmers held more speculative accounts than any other single vocational group, their holdings constituted less than $13 \%$ of the total number of accounts and a far smaller percentage of the total number of speculative futures contracts. Housewives also loomed large as speculators, holding almost $7 \%$ of the open speculative accounts. Bagnell, Analysis of Open Commiturents in Wheat and Corn Futures on the Chicago Board of Trade, Septearber 19, 1934 reported in Hoffman, op. cit. silpra note 30, at 302-304 and Horfaran, Survey 30-1 (1941).

32. The survey cited in note 31 supra found that $92 \%$ of the long speculation accounts involved less than 25,000 bushels each, and that the average size of these accounts was only 10,000 bushels. By way of contrast, hedging accounts averaged 420,000 bushels.

33. HofFMaN, SuRVEy 32 (1941).

34. Id. at $47-8,52$ (1941). The relationship found between prices and the trading of market leaders, id. at 43-60, thus appears to be due to the effect of these trades on prices rather than prediction of price changes by the individual large traders. Id. at 48-49. 
as separate groups..$^{35}$ Analysis has shown that most large speculators are traders in price movements; that is, they follow rather than anticipate price changes, buying when prices are rising and selling when they decline. ${ }^{36}$ Small speculators, on the other hand, have been found, as a group, to trade against price movements. ${ }^{37}$ Thus small speculators exert a stabilizing influence, while the activities of large speculators tend to accentuate fluctuations. Taking the market as a whole, price stability thus depends largely on the excess of trading volume of the former over that of the latter. ${ }^{38}$

\section{Background of Present Federal Regulation}

\section{Need for Regulation}

Exchange trading can effectively serve its hedge facilitating and price stabilizing functions only in a futures market which accurately reflects underlying supply and demand conditions. But experience indicates that a completely unpoliced futures trading system does not fully meet this requirement. First, such a system permits large-scale speculation by individual traders which may result in marked price changes not warranted by valid market considerations. Second, prices may be deliberately distorted by manipulation. Third, information on the volume of trading and other relevant factors necessary for orderly market operations is not readily available. Finally, the need for policing is increased by the fact that unwary speculators are easy prey to unscrupulous "bucket-shop" operations ${ }^{39}$ and other questionable dealer

35. Of course no sharp line of demarcation can be drawn between large and small traders. Several Department of Agriculture studies analyze the transactions of the few traders holding at least 2,000,000 bushels of grain. See, e.g., id. at 46, 50 (1951). However, the standard used to classify large-scale speculators in the 1920 s was 500,000 bushels or more. Id. at 57 .

Federal regulation now limits speculation in wheat, corn, and several other grain futures to maximum net positions or daily trades of 2,000,000 bushels. See note 87 infra.

36. Irwin, The Nature of Risk Assumption in the Trading on Organized Exchanges, 27 Am. Econ. Rev. 267, 270-1 (1937) ; 2 FTC, Rep. on Methods and Operations of Grain Exporters 49-50 (1923). The effects of "movement traders" as distinguished from speculators concerned primarily with supply and demand conditions are analyzed in Irwin, op. cit. supra, at 271-8. The author points out that true speculation, comprising only a small part of futures dealings, promptly brings prices to levels justified by economic conditions and stabilizes prices. Movement trading, on the other hand, aggravates fluctuations and provides no assurance that underlying economic factors will be reflected in commodity price levels. Ibid. See also Hoffman, Survey 50-3 (1941).

37. Hoffrin, Survey 51-2 (1941) ; Hoffman, Past and Present Theory Regarding Futures Trading, 19 J. FARM EcoN. 300, 307 (1937).

38. HofrataN, Survey 49 (1941).

39. The ways of the bucket shop are many and devious, but all bucketing is characterized by the fact that the shop assumes a position opposite that of its customer. Under old-fashioned practice, the shop simply failed to execute the customer's order on the exchange, thus automatically assuming the other side of the "contract" itself. Where buying and selling customers offset each other, the shop collected commissions without 
practices. These inadequacies of the completely free market make some sort of governmental control of futures trading imperative.

\section{State Law}

State law in this field, though voluminous, has not provided the needed regulation. Both statutes and case law deal primarily with the prevention of bucketing and wagering arrangements. ${ }^{40}$ They generally attempt to achieve this result by invalidating futures contracts unless, at the time the transaction was entered into, the parties intended actual delivery of the goods. ${ }^{41}$ But since delivery is initially contemplated in but a small minority of contracts, ${ }^{42}$ this unrealistic standard renders unenforceable even properly executed exchange transactions. ${ }^{43}$ Some states, recognizing the inadequacy of this rule, have

assuming either the risks of the market or the cost of executing the order on the exchange. However, most customers are on the long side so that bucket shops prospered only in a generally declining market. If prices, based on organized commodity exchanges quotations, moved against the bucket-shop, its proprietor could use the margin funds deposited with him to engage in large-scale trades on the exchange in an effort to alter the price trend in his favor. HIII, Gold Bricrs of Speculation 69 (1904). As a last resort, the bucket-shop could simply be closed up and reopened elsewhere. HOFFMan, Future Trading upon Organized Cominodity Markets 357-8 (1932).

Modern bucketing methods, better designed to escape detection, involve executing the customer's order on the exchange and then immediately closing it out without the customer's knowledge. Legis., 45 HARv. L. Rev. 912, 916 n.25 (1932). These practices are now specifically prohibited by the Commodity Exchange Act. See note 72 infra.

40. The statutes pertaining to bucket shops and gamblings contracts are collected in Legis., 45 HaRv. L. Rev. 912, 917 n.26. For the relevant case law, see sources cited in note 41 infra.

41. For more detailed exposition and discussion of this common law "intent-to-deliver" rule, which has been incorporated into most bucketing and wagering statutes, see 6 Williston, Contracts $\$ 1670$ (Rev. ed. 1938); Irwin, Legal Status of Trading in Futures, 32 IlL. L. REv. 155 (1937) ; Taylor, Trading in Commodity Futures-A Ncw Standard of Legality?, 43 YaLE L.J. 63 (1933); Legis., 45 HARv. L. REv. 912 (1932).

42. See note 11 supra.

43. For the purpose of determining validity under the intent-to-deliver test, futures transactions are viewed as two separate contracts. One of these is the contract between the two brokers acting as principals on the exchange. As to this transaction, the intent-to-deliver requirement has been held to be satisfied by the all but universal intention to make an offsetting contract on the exchange. Board of Trade of City of Chicago v. Christie Grain \& Stock Co., 198 U.S. 236 (1905). The courts have, however, not been as generously inclined toward the second contract-that between broker and customer. While there would seem to be no practical reason for treating this part of the transaction differently from that between the brokers, the prevailing view holds broker-customer contracts invalid in the absence of actual intent to deliver, regardless of the validity of the corresponding inter-broker trade. 6 WILIISTon, Contracts $\$ 1672$ (Rev. ed. 1938).

The validity of the inter-broker contract is hardly ever litigated. Legis., 45 HAnv. L. REv. 912, 915 n.18 (1932). However, the illegality of broker-customer contracts has frequently been used as a defense in suits by brokers for commissions or for advances made to customers and in customers' suits to recover margin deposits from 
amended their statutes to render valid all futures trades executed on organized exchanges. ${ }^{44}$ In addition, a few states have developed embryonic regulatory systems. ${ }^{45}$ But, by and large, regulation of exchange trading, based on a recognition of its legitimate economic function, has been left to Congress.

\section{Early Federal Control}

Despite repeated pressure by depression-struck farmers to emasculate the exchange trading system, ${ }^{46}$ federal legislation had a cautious beginning. Early laws, enacted in the $1910 \mathrm{~s}$, were very limited in scope. One of these, the Cotton Futures Act, ${ }^{47}$ dealt only with the grading of cotton deliverable on

brokers. Note, Dealings in Futures, 40 HARv. L. Rev. 638, 639 n.11 (1927). The intent-to-deliver rule thus serves virtually no purpose except to encourage "welching" by broker or customer in case of adverse price changes. See Taylor, Trading in Commodity Futures-A New Standard of Legality?, 43 YALE L.J. 63, 89-94 (1933).

44. Ark. Stat. AnN. \$68-1002 (1948); Fla. Stat. ANv. §851.01 (1943); OKLA. Star. Ann. tit. 15, $\$ 564-5,569$ (1937); S. C. Code ANn. $\$ 6314$ (1942); Tenn. Code Ann. $\$ 11308$ (Williams 1934).

Hedging transactions are exempted from the operation of the otherwise orthodox statute in Minnesota. Minn. Stat. Ans. $\S 614.16$ (1947). And the statutes of Alabama, Florida, and North Carolina accord a similar dispensation to futures dealings by manufacturers and wholesalers in the regular course of business. Ara. Cone ANN. tit. 9, $\S 32$ (1940); Fla. Stat. AnN. \$850.09 (1944); N. C. Gen. Stat. Ann. §16-3 (1943). See Patterson, Hedging and Wagering on Produce Exchanges, 40 YALE L.J. 843 (1931).

45. Illinois and Ohio have statutory provisions making trading in indemnities a criminal offense unless they meet the common law intent-to-deliver test. Indemnities are options to enter into futures contracts at an agreed price. See 2 FTC, REP. ON THE GraIN Trade 332-3 (1920). The same sections also prohibit forestalling the market by spreading false rumors to influence commodity prices, as well as cornering or attempting to corner the market for any commodity. ILr. ANN. STAT. c. $38, \S 328$ (Smith-Hurd 1936); OHio Gen. Code ANN. \$13069 (Page's 1937). The Kansas statutes forbid the exclusion of financially responsible producers' cooperative associations from exchange membership if they have complied with all lawful exchange rules. Kan. Gen. Stat. Ann. §2-1604 (1949); cf. Minn. Stat. Ann. §311.04 (1946).

The only legislation of a supervisory nature consists in the requirement, imposed by several states, that the books of exchanges shall be open to inspection by authorized officials. E.g., OkLA. STAT. ANN. tit. 15, §568 (1938).

46. See note 3 supra. BaER \& WOODRUFF, ConMmodity Exchanges 183-4 (1935).

More than 200 bills were introduced in Congress between 1884 and 1921 providing for prohibition, supervision, or regulation of one sort or another of trading in commodity futures. REP. CE ADMIN. 2 (1937). For a brief summary of some of the more recent restrictive legislative proposals, see Legis., 45 HARv. L. REv. 912, 924 n.58 (1932).

47. 38 Stat. 693 (1914), reenacted, 39 Stat. 476 (1916). For a brief history of the events leading up to the passage of this Act, see BAER \& WOODRUfF, Comsrodiry EXCHANGES 186-8 (1935).

The Act provides for the imposition of a tax of two cents per pound on futures contracts unless stipulated regulatory conditions are met, and now constitutes c. 14 of the Internal Revenue Code. INT. REv. CODE §§ 1920-35. 
futures contracts, 48 and with "difference" systems-methods of determining the price differential between the basis grade ${ }^{49}$ and all other deliverable grades. Two other statutes, the Grain Standards $A c^{t}{ }^{50}$ and the Warehouse Act, ${ }^{51}$ also served merely to raise and standardize conditions of delivery on futures contracts.

The first comprehensive federal effort to regulate exchange trading was the Grain Futures Act. ${ }^{52}$ Limited to transactions in grain futures, ${ }^{53}$ this statute was designed primarily to serve a two-fold function.54 One was to bring to light previously unavailable market information, necessary for orderly trading. This information was also to provide a basis for further legislation, and to permit effective enforcement of the other provisions of the Act. The statute required exchanges and their members to keep records and file reports, ${ }^{\text {t5 }}$ and

48. The Secretary of Agriculture is authorized to promulgate standards for the grading of cotton. INT. REv. CoDE $\$ 1926$. This provision is supplemented by the Cotton Standards Act. 42 Stax. 1517 (1923), 7 U.S.C. $\$ 51$ (1946).

The Cotton Futures Act also provides for the establishment of a minimum grade of cotton deliverable on futures contracts. INT. REv. Cone § 1922(5).

49. The basis or contract grade is the grade of the commodity for which prices are quoted on the exchange. See note 7 supra.

50. 39 STAт. 482 (1916), 7 U.S.C. $\$ 71$ (1946).

51. 39 STAT. 486 (1916), 7 U.S.C. $\$ 241$ (1946).

52. 42 Stat. 998 (1922). This statute was preceded in 1921 by the Futures Trading Act, 42 SxAт. 187 (1921), most of which was promptly declared unconstitutional by the Supreme Court as an invalid exercise of the taxing power. Hill v. Wallace, 259 U.S. 44 (1922). The Grain Futures Act contained substantially the same provisions as the Futures Trading Act, but was based on the commerce clause rather than the taxing power. See Grain Futures Act, $\$ 3$. The constitutionality of the new statute's provisions dealing with regulation of exchanges was sustained in Board of Trade v. Olsen, 262 U.S. 1 (1923).

The Court in the Hill case did not pass on the constitutionality of $\$ 3$ of the Futures Trading Act, imposing a tax of twenty cents per pound on indemnities. See note 45 supra. This provision was declared unconstitutional in Trusler v. Crooks, 269 U.S. 475 (1926). Trading in indemnities was thus not subject to federal restriction from 1926 until 1936 when such transactions were declared unlawful by $\S 4 c(B)$ of the Commodity Exchange Act.

53. Grain was defined by $\S 2(a)$ to include wheat, corn, oats, barley, rye, flax, and sorghum.

54. For a brief synopsis of the general objectives of the Grain Futures Act, see REP. Grain Futures Admintstration 2 (1924).

In addition to the major functions discussed here, the Act also protected farmer cooperatives against arbitrary exclusion from commodity exchange membership. The right of these cooperative associations to become exchange members and thus secure the lower commission rates and other membership benefits was one of the outstanding issues prior to federal regulation. CEA, Twenty-Frve Years of Futures Trading Under Federal Regulation 4 (1950). Further provisions for the protection of cooperatives were included in the Commodity Exchange Act, $\$ \$ 6 \mathrm{a}$ and $6 \mathrm{~b}$. See BAER \& SAXoN, Cosimoditx Exchanges and Futures Trading 255-6 (1949).

55. Section $5(\mathrm{~b})$ of the act made adoption of rules to this effect by the governing board of an exchange a condition precedent for designation of such exchange as a contract market. See page 834 infra. Moreover, under $\$ 4(b)$ the failure of an exchange 
authorized the Secretary of Agriculture to conduct investigations of exchange operations. ${ }^{\text {EB }}$

The other major function of the statute was to curb, through enforced selfregulation by the exchanges, certain practices likely to cause unwarranted price fluctuations. Trading in futures was made unlawful unless conducted on exchanges designated by the Secretary of Agriculture as "contract markets." To be so designated, exchanges were required to prevent manipulation of prices and cornering of commodities, ${ }^{58}$ as well as dissemination of false or misleading market information. ${ }^{59}$ Failure to comply with these requirements might result in suspension or revocation of the contract market designation, ${ }^{60}$ which, in effect, would close the exchange. The only direct control over individual traders was a provision imposing criminal penalties for certain actions. ${ }^{61}$

With its main emphasis on control over exchanges rather than individual traders, the Act proved ineffectual. The power to ban futures trading should an exchange fail to exercise the requisite self-discipline-the statute's only sanction against exchanges-was too drastic. Such action would inevitably injure innocent traders. It is not surprising, therefore, to find that this penalty was never successfully imposed. ${ }^{62}$ Moreover, numerous harmful dealer and broker practices remained entirely unrestricted.

member to keep written records of all trades executed by him rendered these transactions unlawful. This might subject him to denial of exchange trading privileges, see note 59 infra, and criminal penalties under $\$ 9$.

56. Section 8.

57. Section 4(b).

58. Section $5(\mathrm{~d})$.

59. Section $5(\mathrm{c})$. In addition to these requirements for designation as a contract market and those set out in note 55 supra, an exchange had to comply with three other conditions to be designated a contract market: (1) It could not become a contract market unless it was located at a terminal market where cash grain was sold in sufficient volume to reflect general grain prices and where an approved official inspection service was available. $\$ 5(a)$. (2) The exchange was not permitted to exclude financially responsible, lawfully formed and conducted producers' cooperatives from exchange membership. $\$ 5(\mathrm{e})$; see note 54 supra. (3) The governing board of the exchange was required to effectuate orders of the Secretary of Agriculture promulgated under $\$ 6(\mathrm{~b})$ directing exchanges to refuse exchange trading privileges to violators of the Act. $\$ 5(f)$.

60. Section 6(a). Revocation or suspension of an exchange's contract market designation could be ordered by a commission consisting of the Secretaries of Agriculture and Commerce and the Attorney General (which under the Commodity Exchange Act became the Commodity Exchange Commission), subject to review by a circuit court of appeals.

61. Section 9 makes it a misdemeanor to (1) execute a futures contract which is not properly recorded, or (2) enter into a futures transactions on an exchange not designated as a contract market, or (3) transmit in interstate commerce false, misleading, or knowingly inaccurate crop and market reports.

62. Only once did the commission try to invoke its power. In 1932 it ordered a 60-day suspension of the contract market designation of the Chicago Board of Trade for refusing to admit a producers' cooperative to membership in its clearing association. On appeal the Seventh Circuit Court of Appeals sustained the commission's view that $\S 5(\mathrm{e})$ entitled producers' cooperatives to clearing house privileges in addition to exchange mem- 
Despite these shortcomings, however, the Grain Futures Act remained unamended for fourteen years. It was not until 1936, with the passage of the far more comprehensive Commodity Exchange Act, ${ }^{63}$ that the inadequacies of the earlier Act were remedied. ${ }^{64}$

bership, and also upheld the constitutionality of $\S 6(\mathrm{a})$ authorizing suspension or revocation of contract markets designations by the commission. But the court set aside the order and remanded the case to the commission to make further findings on the cooperative's compliance with the Capper-Volstead Act, 42 STAT. 388 (1922), 7 U.S.C. §291 (1946). Such compliance was held necessary to constitute the cooperative a "lawfully conducted cooperative association of producers" under $\$ 5(\mathrm{e})$ of the Grain Futures Act. Board of Trade of City of Chicago v. Wallace, 67 F.2d 402 (7th Cir. 1933), cert. denied, 291 U.S. 680 (1934). Shortly after this decision the Board of Trade acquiesced in admitting the cooperative to clearing-house privileges. The suspension order thus never went into effect. See Rep. Grain Futures Adminnstration 5-6 (1934).

63. 49 STAT. 1491 (1936), as amended, 7 U.S.C. $\$ 1$ (1946) and 7 U.S.C. $\$ 12-1$ (Supp. 1949).

One of the immediate causes of the passage of the Commodity Exchange Act was the Supreme Court's decision in Wallace v. Cutten, 298 U.S. 229 (1936). The Court there held that the Secretary of Agriculture could not order the denial of trading privileges to past manipulators under $\S 6(b)$ since that provision in the Grain Futures Act applied only to a person who "is manipulating" commodity prices. 42 STAT. 1002 (1922). As a result of this decision, the only direct sanction provided by the Grain Futures Act against manipulators became a virtual nullity. The Commodity Exchange Act altered $\S 6(\mathrm{~b})$ to include past manipulation, which was also made a misdemeanor under $\$ 9$ of the 1936 Act.

64. In the meantime, however, the exchanges themselves enacted rules to improve trading conditions. Especially important were those establishing limits on daily price fluctuations. See, e.g., Chicago Board of Trade, Rule 81; N.Y. Cotton Exchange, Rule 25. These limits were first adopted as an emergency measure during the banking crisis of 1933, and are still in effect on a number of commodities. Present daily fluctuation limits on the principal exchanges for wheat, rye, barley, flaxseed, and soybeans are ten cents per bushel, for corn, eight cents, and for oats, six cents. CEA, TwENTY-FIVE YEARS of FuTURES Trading under Federai Regulation 4 (1950). Cotton fluctuations limits, not applicable during the current delivery month, are ten dollars per bale above or below the previous day's closing price, subject to the further limitation that the price range in one day is not to exceed ten dollars. Communication to the YaLE LAw Journal from J.M. Mehl, CEA Administrator, dated December 21, 1950, in Yale Law Library.

For a discussion of exchange rules setting minimum margin requirements, another significant self-regulatory measure, see pages $344-45$ infra.

A further means of self-regulation is provided by rules empowering exchanges to "stop trading . . . in any of the future contracts of any commodity by reason of any emergency or otherwise." Chicago Board of Trade, Rule 251. See also N.Y. Cotton Exchange, Rule 28; Commodity Exchange, Inc., \$408; Minneapolis Chamber of Commerce, Rule 418. A significant recent application of these rules by the grain exchanges occurred in May and June 1946 when OPA ceiling prices on grain were increased. To meet the problem of a sudden price increase, the Chicago Board of Trade and two other exchanges adopted a series of regulations under their emergency rule. A suit against the Chicago Board of Trade alleging that these regulations constituted price fixing in violation of $\S 1$ of the Sherman Act was unsuccessful. Cargill v. Board of Trade of City of Chicago, $164 \mathrm{~F}$. 2d 820 (7th Cir. 1947). For an extensive discussion of these regulations and the effect of the May 1946 price ceiling changes on futures trading, see CEA, 


\section{The Commodity Exchange Act}

The Commodity Exchange Act constitutes the statutory basis of present federal futures trading regulation. The scope of this control, later broadened by two amendments, ${ }^{65}$ now covers most domestically produced agricultural commodities in which futures trading is conducted. ${ }^{66}$ To the main purposes of the Grain Futures Act, securing market information and eliminating price distortions, the new legislation added another: protection of traders against fraudulent practices by dealers. In addition, the mechanics for achieving the earlier objectives were improved considerably. This was accomplished chiefly by extending federal control directly, through registration requirements and penal sanctions, to individual futures commission merchants, floor brokers, and cus-

Effect on futures Trading in Grains of Changes in Price Ceicings of May 13, 1946 passim (1946).

65. 52 Stat. 205 (1938) and 54 Stat. 1059 (1940) amending §2(a), 7 U.S.C. §2 (1946). The 1938 amendment added wool tops to the commodities subject to federal regulation. In 1940 control was extended to fats and oils (including lard, tallow, cottonseed oil, peanut oil, soybean oil and all other fats and oils), cottonseed meal, cottonseed, peanuts, soybeans, and soybean meal.

66. REP. CE ADMIN. 4 (1941).

The commodities in which futures are now traded and the major exchanges on which such transactions are conducted are listed in the following table:

\begin{tabular}{|c|c|c|c|}
\hline Oon & Mrarket & omr & Mrarket \\
\hline $\begin{array}{l}\text { Bran* } \\
\text { Butter* } \\
\text { Cocoa } \\
\text { Coffee } \\
\text { Copper } \\
\text { Corn* } \\
\text { Cotton* } \\
\text { Cottonseed meal* } \\
\text { Cottonseed oil* } \\
\text { Eggs* } \\
\text { Flaxseed* } \\
\text { Hides* } \\
\text { Lard* } \\
\text { Lead } \\
\text { Oats* } \\
\text { Onions }\end{array}$ & $\begin{array}{l}\text { Kansas City Bd. of Trade } \\
\text { Chicago Mercantile Exch. } \\
\text { N.Y. Cocoa Exch. } \\
\text { N.Y. Coffee \& } \\
\text { Sugar Exch. } \\
\text { Commodity Exch., Inc. } \\
\text { Chicago Bd. of Trade } \\
\text { Kansas City Bd. of Trade } \\
\text { N.Y. Cotton Exchange } \\
\text { New Orleans Cotton } \\
\text { Exch. } \\
\text { Memphis Merch. Exch. } \\
\text { Cl. Ass'n } \\
\text { N.Y. Produce Exchange } \\
\text { Chicago Mercantile Exch. } \\
\text { Minneapolis Grain Exch. } \\
\text { Commodity Exch., Inc. } \\
\text { Chicago Bd. of Trade } \\
\text { Commodity Exch., Inc. } \\
\text { Chicago Bd. of Trade } \\
\text { Chicago Mercantile Exch. }\end{array}$ & \begin{tabular}{|l} 
Pepper \\
Potatoes* \\
Rice* \\
Rubber \\
Rye* \\
Shorts* \\
Soybeans* \\
Soybean meal* \\
Soybean oil* \\
Sugar \\
Tin \\
Wheat* \\
Wool \\
Wool tops* \\
Zinc
\end{tabular} & $\begin{array}{l}\text { N.Y. Produce Exchange } \\
\text { N.Y. Mercantile Exch. } \\
\text { N.Y. Mercantile Exch. } \\
\text { Commodity Exch., Inc. } \\
\text { Chicago Bd. of Trade } \\
\text { Kansas City Bd. of Trade } \\
\text { Chicago Bd. of Trade } \\
\text { Memphis Merch. Exch. } \\
\text { C1. Ass'n } \\
\text { Chicago Bd. of Trade } \\
\text { N.Y. Produce Exchange } \\
\text { N.Y. Coffee \& } \\
\text { Sugar Exch. } \\
\text { Commodity Exch., Inc. } \\
\text { Chicago Bd. of Trade } \\
\text { Kansas City Bd. of Trade } \\
\text { Minneapolis Grain Exch. } \\
\text { Wool Assoc. of N.Y. } \\
\text { Cotton Exch. } \\
\text { Wool Assoc. of N.Y. } \\
\text { Cotton Exch. } \\
\text { Commodity Exch., Inc. }\end{array}$ \\
\hline
\end{tabular}

* Commodities subject to federal regulation under the Commodity Exchange Act as amended. 
tomers. ${ }^{67}$ Revocation or suspension of registration, coupled with the criminal penalties provided by the Act against individual violators, constitutes a far more workable system of sanctions than closing exchanges which permit trading by offending dealers.

The primary regulatory agency under the Act is now the Commodity Exchange Authority, ${ }^{68}$ a bureau in the Department of Agriculture. Some important controls over the exchanges, however, are reserved to the Commodity Exchange Commission, consisting of the Secretaries of Agriculture and Commerce and the Attorney-General. ${ }^{60}$

\section{Protection of Customers}

To accomplish its purpose of protecting traders from unscrupulous dealers, the Act contains a broad prohibition against defrauding or deceiving traders. ${ }^{70}$ It also proscribes such specific practices as bucketing ${ }^{71}$ and executing countertransactions to customers' orders without their permission. ${ }^{72}$ These activities not only constitute frauds on traders but also cause price distortions. In addition, the statute requires that futures commission merchants segregate and separately account for margin funds ${ }^{73}$ deposited with them by customers. ${ }^{74}$ This provision, complemented by another prohibiting use of a customer's funds

67. The Act imposes a registration requirement upon futures commission merchants, $\S 4 \mathrm{~d}(1)$, and floor brokers, $\$ 4 \mathrm{e}$. The definition of futures commission merchant in $\S 2(\mathrm{a})$ covers all brokers and brokerage firms who solicit or accept orders for futures trades. A floor broker is the person who places the order on the exchange. Ibid.

68. Before the establishment of the Authority in January 1947, the Commodity Exchange Act had been administered by the Commodity Exchange Administration (July 1936 to February 1942) and by a succession of agencies during World War II. The Grain Futures Act, prior to the passage of the 1936 legislation, was administered by the Grain Futures Administration.

69. The Commission has sole authority to (1) set maximum limits on the daily trades and total net futures commitments of speculative traders. $\$ 4 a(1)$ and (2). These limits are not applicable to bona fide hedging transactions as defined in the act. $\S 4 \mathrm{a}(3)$. See note 87 infra. (2) suspend or revoke an exchange's contract market designation. $\$ 6(a)$. See note 62 supra. (3) hear appeals by an exchange from the refusal of the Secretary of Agriculture to designate such exchange a contract market. $\$ 6(a)$. (4) hear complaints by an exchange seeking to deny membership privileges to producer's cooperatives on grounds set out in the act. $\$ 6 a(1)$. (5) issue cease and desist orders against an exchange, or any director, officer, agent or employee thereof for violation of any provision of the Act or order of the Secretary of Agriculture or the Commodity Exchange Commission. Refusal to obey subjects offenders to criminal penalties. $\$ 6 \mathrm{~b}$.

70. Sections $4 b(A)$ and $(C)$.

71. See note 39 supra.

72. Section $4 b(D)$. This practice constitutes the modern form of bucketing. It consists in making a trade on the exchange opposite to that of the customer, thus, in effect, immediately closing out the customer's position. See note 39 supra. infra.

73. For a discussion of the nature of margins in futures transactions, see page 844

74. Section $4 d(2)$. 
to finance anyone else's transactions, ${ }^{75}$ protects traders should the broker fail financially. In effect it makes customers preferred rather than general creditors as they had been previously. ${ }^{76}$

\section{Acquisition of Market Information}

The statute also facilitates dissemination of trade information essential for both enforcement and statistical purposes. In addition to the reporting and record-keeping provisions of the Grain Futures Act, ${ }^{77}$ exchanges are now required to furnish the $\mathrm{CEA}$ with copies of their by-laws and rules, ${ }^{78}$ and must permit inspection of their books by authorized agents of the Departments of Agriculture and Justice. ${ }^{79}$ Futures commission merchants and floor brokers in order to qualify for registration must furnish such information as the CEA requires. ${ }^{30}$ Finally, all traders whose daily transactions or net positions ${ }^{81}$ equal or exceed levels set by the Secretary of Agriculture 82 are required to keep detailed records of their trading activities and submit reports. ${ }^{83}$ These reports provide statistics on the division of trading between hedging and speculation and the effects of large transactions on price movements.

\section{Control of Manipulation}

The fundamental purpose of the Commodity Exchange Act still remains the elimination of those practices which result in price distortions or unwarranted

75. Ibid.

76. Communication to the YALE LAw Jouknal from J.M. Meh1, CEA Administrator, dated March 13, 1951, in Yale Law Library.

77. See note 55 supra.

78. Section $5 a(1)$.

79. Section $5 a(2)$.

80. Section $4 \mathrm{f}(1)$.

81. When the trader's long or short position in any one future reaches or exceeds the levels set out in note 82 infra, he must submit the required information on all his futures transactions in that commodity. REP. CEA 29 (1950).

82. The levels in effect on June 30, 1950 were as follows:

\begin{tabular}{l|c}
\multicolumn{1}{c}{ Commodity } & Quantity \\
\hline Wheat, corn, oats, rye, barley, flaxseed, soybeans, & \\
and grain sorghums & 200,000 bushels \\
Milled rice & 56,000 pockets \\
Cotton & 5,000 bales \\
Wool tops & 125,000 pounds \\
Cottonseed oil and soybean oil & 25 carlots \\
Lard & 900,000 pounds \\
Millfeeds (bran, shorts, middlings) & 600,000 pounds \\
Cottonseed meal and soybean meal & 1,000 tons \\
\end{tabular}

REP. CEA 29 (1950).

S3. Section 4i. 
fluctuations. Such price influences may be caused more or less unintentionally by very extensive trading, or they may be the result of planned action, known as manipulation.

The dissemination of full and accurate market information is one of the most effective means of preventing successful manipulation. Reports of the Secretary of Agriculture as to supply, demand, and other market conditions provide much of the information necessary for orderly trading. ${ }^{84}$ And misleading influences are minimized by a specific prohibition in the Commodity Exchange Act against the circulation of false market rumors. ${ }^{85}$

However, the most significant provision of the Commodity Exchange Act pertaining to price influences is aimed at the manipulative power of large traders. On the basis of a legislative finding that excessive speculation may cause sudden and unreasonable price fluctuations, ${ }^{88}$ the Commodity Exchange Commission was given power to set maximum limits on the daily volume of speculative trading and net speculative futures holdings of individual traders. ${ }^{87}$ This authority is the Act's most effective means both to restrict the manipulative capacity of sizable speculative holdings and to limit price changes brought about involuntarily by the activities of large speculators.

The Act also empowers the Secretary of Agriculture to take measures to lessen the susceptibility of exchange markets to manipulation. This susceptibility is due partly to the unwillingness of the longs to take delivery or the inability of shorts to make it. ${ }^{88}$ The longs' unwillingness, which is to a

84. "[T] $]$ he success or failure of traders in commodity futures is largely dependent upon their ability to secure, interpret, and evaluate market information concerning production, distribution, and trading activities. ..." REP. CE ADMTN. 18-19 (1937). See also Note, Prevention of Commodity Futures Manipulation under the Commodity Exchange Act, 54 HARv. L. REv. 1373, 1375 (1941). On price manipulation generally see 7 FTC, Rep. on the Gratn Trade c. 7 (1926).

85. Section 9 provides criminal penalties for knowingly or carelessly transmitting in interstate commerce false or misleading or knowingly inaccurate reports concerning crop or market information that tend to affect commodity prices. Adoption of exchange rules to this effect is also a condition precedent to an exchange's designation as a contract market. $\$ 5(\mathrm{c})$.

The effect which a false rumor may have on market prices was dramatically illustrated in 1930 when a spurious publicly-circulated telegram containing false information as to a large speculator's financial condition brought about a sharp decline in wheat futures prices. See Rep. Grain Futures Adaitnistration 6-7 (1931).

86. Section $4 a(1)$.

87. Sections $4 \mathrm{a}(1)$ and $4 \mathrm{a}(2)$. Hedging transactions are specifically exempted by $\S 4 \mathrm{a}(3)$. Trading and position limits now in effect for wheat, corn, oats, barley, and flaxseed were established in 1938. Limits were set for rye at the same time, but these were reduced in 1945 . The 1940 limits on cotton speculation also were lowered, in 1946. 17 CoDE FED. REGs. $\$ \$ 150.1-150.3$ (1949). In February 1951, the Commodity Exchange Commission held hearings for the purpose of establishing soybean and egg speculative trading limits. Communication to the YaLE LAw Jourdal from J.M. Mehl, CEA Administrator, dated March 13, 1951, in Yale Law Library.

88. See Hoffman, Future Trading Ufon Organized Cominodity Mirkets 314-18 (1932). 
great extent inherent in the present futures trading system, ${ }^{80}$ makes it possible for the manipulating short seller to buy out their contracts at deflated prices. In this situation the Secretary can aid the long futures holder by requiring up to ten days' notice of intended delivery. ${ }^{90}$ As for the shorts, their inability to make required delivery results from shortages of deliverable commodity supplies likely to occur towards the end of the delivery month. This can be remedied by the Secretary's giving the shorts a "breathing spell" of up to ten days after the cessation of trading in the delivery month. ${ }^{91}$ The seller is thus enabled to acquire supplies located elsewhere than at the delivery point. ${ }^{22}$

In addition to these indirect measures, the Act makes any attempts to manipulate prices and corner commodities ${ }^{93}$ criminal offenses. ${ }^{94}$ Moreover, engaging in manipulative activities is one of the grounds for revoking or suspending the registration of commission merchants and floor brokers. ${ }^{95}$ Effective enforcement of these sanctions requires a clear, generally accepted conception of what constitutes manipulation.

This issue was squarely posed for the first time under the Commodity Exchange Act in General Foods Corp. v. Brannan.96 In that case, four individuals, a commodity brokerage firm, and the General Foods Corporation had carried on extensive speculative operations in May 1944 Chicago rye futures.

89. Almost all futures transactions are made for speculative or hedging purposes and not to obtain commodities. Moreover, speculators rarely have the necessary storage capacity to accommodate delivered goods. See Hoffman, Future Trading Upon Organized Commodity Markets in the United States 314 (1932). See also a finding to this effect by the Secretary of Agriculture in the order cited in note 91 infra.

90. Section $5 a(5)$. See note 91 infra.

91. Section $5 \mathrm{a}(4)$. Under this section, on February 17, 1938, the Secretary of Agriculture promulgated an order permitting the settlement of wheat, corn, oats, barley, rye, and flaxseed futures for seven days after the cessation of trading in such future. 17 CODE FED. REGS. § 100.1 (1949).

The issuance of orders under both $\S \S 5 \mathrm{a}(4)$ and $5 \mathrm{a}(5)$ must be preceded by a hearing and such orders are not applicable to contracts in effect at the time of promulgation. Thus these provisions are not available for. use in case of emergency.

92. See, generally, Hoffman, Sunvey 60-70 (1941). To further reduce artificial influences upon commodity prices, the Act also contains provisions prohibiting fictitious trades, $\S 4 c(A)$, trading in indemnities, $\S 4 c(B)$, and any transactions used to cause an untrue prices to be reported, $\S 4 \mathrm{c}(\mathrm{C})$.

93. The Supreme Court adiopted the following definition of a corner in U.S. v. Patten, 226 U.S. 525 (1913) (conspiracy to run a corner in cotton held violation of Sherman Act \$1): “'Running a corner' consists, broadly speaking, in acquiring control of all or the dominant portion of a commodity with the purpose of artificially enhancing the price, 'one of the important features of which,' to use the language of the Government's brief, is the purchase for future delivery, coupled with a withholding from sale for a limited time ...'"Id. at 539-40. The Court also observed that "not improbably in actual usage the expression includes modified modes of attaining substantially the same end." Id. at 540 .

94. Section 9.

95. Section 6(b).

96. 170 F.2d 220 (7th Cir. 1948), 37 Geo. L.J. 450 (1949), 97 U. of PA. L. Rev. 572 (1949). 
They had also accumulated large speculative stocks of cash rye, which, by the end of May 1944, amounted to $89 \%$ of the deliverable supply in Chicago. ${ }^{97}$ On May 13, General Foods, which at that time held over 7,000,000 bushels of cash rye, bought from three of the individuals involved nearly $2,000,000$ additional bushels of "distress" rye which the sellers would otherwise have been forced to dump on the market.9s Thereafter the CEA brought charges against all these speculators for alleged manipulation of the price and cornering of both rye futures and cash rye. The Department of Agriculture judicial officer held that all the respondents had manipulated the price of rye futures and cash rye by means of the $2,000,000$ bushel distress rye transaction. However, he found that they were not guilty of manipulation and cornering by virtue of their other operations, but that these other operations did constitute attempts at manipulating and cornering. ${ }^{99}$

On appeal to the Seventh Circuit Court of Appeals, the orders of the departmental judicial officer were set aside on the ground that the charges were not supported by the "weight of evidence."100 In vacating that part of the

97. Shepherd, Marketing Farm Products 126 (1946).

98. 6 Agric. Dec. 288, 304 (1947).

99. Id. at 304-318 (1947).

100. This "weight of evidence" formula, prescribed by the Commodity Exchange Act to establish the scope of appellate review, $\S 6(\mathrm{~b})$, had not theretofore received any definitive judicial interpretation. Cf. Nichols \& Co. v. Secretary of Agriculture 131 F.2d 651, 654 (1st Cir, 1942) (dictum to the effect that, since Congress used the words "weight of evidence" rather than merely "evidence" or "substantial evidence," court of appeals might have authority to consider the evidence de novo).

The Commodity Exchange Act review formula is used in no other federal regulatory statute. 37 Geo. L.J. 450, 451 (1949). Other acts contain a variety of other formulae. The Federal Trade Commission Act provides that the Commission's findings of fact shall be conclusive "if supported by evidence." 52 STat. 113 (1938), 15 U.S.C. \$45(c) (1946). The Securities Exchange Act requires "substantial evidence," 48 STAT. 881 (1934), 15 U.S.C. \$78y (a) (1946), as do the Fair Labor Standards Act, 52 Stat. 1065 (1938), 29 U.S.C. $\$ 210$ (1946), and several other statutes. Still another formula appears in the Walsh-Healey Act, which uses the words "if supported by the preponderance of the evidence." 49 STAT. 2038 (1936), 41 U.S.C. $\$ 39$ (1946).

The Walsh-Healey Act wording, which most closely parallels that of the Commodity Exchange Act, has not been judicially construed. 37 GEo. L.J. 450, 452 (1949). However, the "differences in language [in the review provisions of the other acts cited above] seem to involve no difference in meaning." Rep. Atr'y. Gen. Comrs. Ad Proc. 89 (1941). These provisions have been tacitly assumed to mean "supported by substantial evidence." 37 GEO. L.J. 450, 452 (1949).

Nevertheless, the court in the General Foods case held that the standard to be employed under the Commodity Exchange Act was "something other than the 'substantial evidence rule." $170 \mathrm{~F} .2 \mathrm{~d}$ at 223 . It interpreted the statutory formula to mean that departmental orders may be vacated if not supported by the "preponderance or greater weight" of the evidence. $I d$. at 224. This deviation from the substantial evidence rule derives no support from the legislative history of the Act. 37 GEO. L.J. 450, 452 (1949). Although the application of the substantial evidence rule in the General Foods case would probably not 
judicial officer's order based on his finding that the 2,000,000 bushel distress rye transaction constituted manipulation, the court offered the first judicial interpretation of that concept as used in the Commodity Exchange Act. It found that the distress rye operation involved merely stabilization of a "natural" price at its existing level in order to protect the participants' other rye and futures investments. The court considered this a valid form of "selfpreservation." The operation was therefore held not to amount to manipulation within the meaning of the Act.

The General Foods opinion distinguished U.S. v. Socony-Vacuum Oil Co., ${ }^{101}$ a price-fixing case under the Sherman Act, on the extremely tenuous ground that the price there sought to be stabilized was an artificial one created by the acts of the defendants. ${ }^{102}$ This distinction overlooks the fact that any operation which interferes with market conditions will result in a manipulated, i.e., artificial, price, no matter how "natural" the price may have been before the operation. Since both maintaining an existing price and intentionally causing price changes result in artificial prices, the definition of manipulation should be expanded to cover both. This has long been the law in the securities field, where the Securities Exchange Act of 1934 proscribes certain stock

have changed the result, the preponderance requirement does appear to place on the Department a heavier burden of proof before an appellate tribunal than must be sustained by other federal regulatory agencies.

For a recommendation that the Commodity Exchange Act be amended by substituting the words "substantial evidence" for "weight of the evidence," see Sellers, ADMrNISTRAtive Procedure and Practice in the Departarent of Agriculture under the Comarodity Exchange Act 81-83 (Dep't of Agric. 1939).

101. 310 U.S. 150 (1940). Since "manipulation" as used in the Commodity Exchange Act had not theretofore been judicially construed, the Government in the General Foods case urged upon the court the Supreme Court's interpretation of manipulation in the anti-trust field. Brief for Respondents, pp. 29-30. In the Socony-Vacuum case the Supreme Court had said in this connection: "In this case, the result was to place a floor under the market-a floor which served the function of increasing the stability and firmness of market prices. This was repeatedly characterized as stabilization. But in terms of market operations stabilization is but one form of manipulation." 310 U.S. at 223.

102. The court offered as another basis of distinction the fact that the SoconyVacuum case involved "a statute [the Sherman Act] which made it illegal per se to combine for the purpose of "raising, depressing, fixing, pegging, or stabilizing the price of a commodity." 170 F.2d at 230. But there is no such provision in the Sherman Act, the relevant portion of which simply declares combinations in restraint of trade to be illegal. 26 SтAт. 209 (1890), 15 U.S.C. \$1 (1946). This has been construed by the Supreme Court to make price fixing illegal per se. And in the Socony-Vacunm case price fixing is implicitly equated to manipulation, which is there held to include raising, depressing, fixing, pegging, or stabilizing prices. 310 U.S. at 224. The prohibition of these acts, attributed by the court in the General Foods case to the Sherman Act, is actually quoted from the interpretation of that statute in the Socony-Vacuum opinion. Thus, in fact, the Socony-Vacuum case holds price stabilization to violate a much more general and ambiguous provision than the Commodity Exchange Act prohibition of manipulation involved in the General Foods case. 
transactions conducted for the purpose of "pegging, fixing, or stabilizing" prices. ${ }^{103}$

\section{Control of Excessive Speculation}

Trading Limits. Price distortions may result not only from manipulation but also as an unintended incident of the operations of very large speculators. The power vested in the Commodity Exchange Commission to set individual daily trading and net commitment limits ${ }^{104}$ is the government's best weapon against such "excessive" speculation. The limit-setting power has been criticized as an interference with the hedge facilitating function of speculation on the theory that large accounts carry the hedging load. ${ }^{105}$ This contention has, however, been adequately answered by the discovery that it is the small rather than the large accounts which generally accommodate hedging. ${ }^{106}$

Trading and position limits, now in effect for most of the major commodities, ${ }^{107}$ are low enough to preclude major manipulative efforts such as were possible in the past. ${ }^{108}$ In the case of rye and cotton, experience showed that the original levels were too high to accomplish their purpose. ${ }^{100}$ They were consequently reduced in 1945 and 1946, respectively. ${ }^{110}$ And the Commission is presently preparing limits for two additional commodities, soybeans and eggs, in which extensive speculation is now conducted. ${ }^{111}$ These restrictions will undoubtedly reduce in the future the disturbing effects of large speculative operations.

In view of the vital patt trading limits play in futures regulation, it is important that the mechanics for establishing and altering these limits be as efficient as possible-a goal not achieved under the present scheme. Acting on the assumption that three departmental heads were better than one, Congress vested control over trading limits in the Commodity Exchange Com-

103. Securities Exchange Act of 1934, $\$ 9$ (a) (6), 48 STAT. 889 (1934), 15 U.S.C. $\$ 78 i(a)(6)$ (1946). Because of conditions peculiar to the business of raising capital, the SEC does permit price stabilization of new issues. For SEC regulations to this effect, see 97 U. of PA. L. REv. 572, 573 n.9 (1949). See also Comments, Regulation of Stock Market Manipulation, 56 YALE L.J. 509 (1947); Market Manipulation and the Securities Exchange Act, 46 YaLE L.J. 624 (1937).

104. See notes 69 and 87 supra.

105. Shepherd, Marketing Farm Products 130 (1946).

106. Hearings before Committee on Agriculture and Forestry on H.R. 6772, 74th Cong., 2d Sess. 211 (1936); P. Mehl, Trading in Futures and Price Fluctuations, 16 J. Fara Econ. 488 (1934).

107. See note 87 supra.

108. Successful manipulations before the Act involved very large futures holdings. For example, while Cargill was running its 1937 corn corner, its corn future holdings never fell below 6,000,000 bushels. Hofraran, Survey 69 (1941). Corn position limits are now set at 2,000,000 bushels. 17 CODE FED. REGs. $\$ 150.1$ (1949). See also REP. CEA 3 (1947).

109. The inadequacy of rye limits was pointed up by the transactions involved in the General Foods case. See pages $840-41$ stipra.

110. 17 CODE FED. REGS. $\$ \$ 150.2,150.3$ (1949).

111. See note 87 sispra. 
mission. This anomalous body has no regular personnel or specific appropriation. It depends on the CEA for virtually all of the technical work incident to the setting of trading limits, ${ }^{112}$ to date the Commission's chief activity. ${ }^{113}$ This diffusion of responsibility among three cabinet members appears unnecessary in view of the fact that they have apparently consistently followed the recommendations on trading limits made to them by CEA officials. ${ }^{114}$ The Commission should be abolished and its responsibilities shifted to the Secretary of Agriculture, who already administers most of the provisions of the Act. ${ }^{115}$

Margin Requirements. While the power to set trading limits permits the government to curb speculative transactions of large traders, no method is presently available to federal authorities to reduce price fluctuations brought about by the forced liquidation of a sizable number of small speculative accounts. ${ }^{116}$ Federal officials have long been seeking to remedy this situation by urging enactment of legislation empowering the Secretary of Agriculture or the President to set minimum margin requirements for all speculators. ${ }^{117}$ These regulations would specify minimum percentages of the contract price which the customer would have to deposit with his broker when originally entering into a futures transaction.

Beginning in 1933, all of the exchanges have themselves imposed some mandatory minimum margin requirements upon non-member traders. ${ }^{118}$

112. SELLERS, op. cit. supra note 100 , at 79-80.

113. Besides establishing speculative trading and position limits, the Commodity Exchange Commission has handled only two matters since enactment of the Commodity Exchange Act:

(1) A complaint by Cargill, Inc., against the Chicago Board of Trade for alleged violation of the Commodity Exchange Act, by requiring Cargill to liquidate some of its large 1936 and 1937 futures holdings and in extending the time for delivery on some of these futures, was dismissed by the Commission after extensive hearings. Cargill v. Chicago Board of Trade, CE-A Docket No. 6 (1940).

(2)' In another dispute between Cargill and the Chicago Board of Trade, the Commission ruled on the validity of nine Board rules and regulations imposed on warehouses in order for their receipts to be acceptable in satisfaction of futures contracts made on the Board of Trade. In re Application of Cargill, Inc., for a Declaratory Order, Dec. 14, 1950 (mimeographed).

114. Inquiries to the three Departments whose heads constitute the Commission have not revealed a single instance in which one of these members objected to the recommendations made to the Commission by a presiding officer who conducts hearings for this purpose. This presiding officer is either the CEA Administrator or a CEA official appointed by him. 17 CoDE FED. REGs. $\$ 0.77$ (b) (1949). No record of the deliberations of the Commission appears to be available. For the procedure followed in preparing trading limits and the practice of the Department of Justice in this respect, see Communication to the Yale Law Journal from J. Stephen Doyle, Jr., Special Assistant to the Attorney General, dated April 13, 1951, in Yale Law Library.

115. SELLERS, op. cit. supra note 100 , at 79-80.

116. REP. CEA 7 (1950); Hearings, supra note 20, at 2-4, 27-8 (1948).

117. See note 1 supra.

118. See hectographed table, Minnmum Initiar Margrns Prescribed by Exchanges, 
These margins are set primarily to protect brokers against customers' defaults (since brokers are responsible to the exchange for defaults on contracts) as well as to protect other customers of a broker forced into bankruptcy by such defaults. ${ }^{118}$ Athough the immediate purpose of the change from permis. sive to mandatory margin requirements by a number of the largest exchanges in 1933 was to restrict price fluctuations due to dealings of financially irresponsible speculators, ${ }^{120}$ margin levels are still set primarily with a view to the protective function rather than to minimize price fluctuations. ${ }^{121}$

The reluctance of exchanges to raise margin requirements has occasionally been overcome by strong moral suasion by government officials. A very active speculative market in wheat futures in March 1947 brought a request from the CEA that exchanges raise their minimum margins to $25 \% .{ }^{122}$ This request was complied with, but only temporarily; margin requirements were again lowered in May. A further request for margin increases to $33 \% / 3 \%$ was made by the Department in September 1947 but it was not until after a Presidential speech the following month ${ }^{123}$ that the desired margins were imposed. During the first month under the $33 \mathrm{x} / 3 \%$ requirement, the volume of trading was reduced by $45 \% .^{124}$ The increase in margins failed to prevent a break in wheat and corn prices in February 1948, in which liquidation of small accounts played a significant role. This may, however, be explained at least in part by the fact that extensive holdings of wheat and corn futures had already been acquired in October 1947 when the 33I/3\% margin was established.125

The close causal relationship between forced liquidations of small, inadequately margined speculative holdings and several recent price breaks ${ }^{126}$ compels the conclusion that reasonable margin regulation by the Secretary of Agriculture would help eliminate these sharp and unnecessary fluctuations.

as of August 17, 1950 on Speculative Futures Transactions in Specified ConMODITIES, prepared by the CEA.

"In general, speculative margins established by the exchanges are applied only to 'outside' traders. For example, members of the Chicago Board of Trade who execute their own transactions on the trading floor are not required by the rules to deposit speculative margins. Similarly members who clear their own speculative transactions through the clearing-house of the exchange need deposit only the much lower clearinghouse margin." Report of the CEA Administrator, July 31, 1950, on the effect of commodity speculation on prices for the first month of the Korean war, quoted in 96 Cong. Rec. 11952 (Aug. 3, 1950).

On the historical development of mandatory exchange margin requirements, see Hearings, supra note 20 , at 100 .

119. Id. at 104 .

120. Id. at 100 .

121. Id. at 104 .

122. Id. at 102 .

123. For a quotation of the relevant portion of President Truman's address of October 5, 1947, see id. at 103.

124. Id. at 4 .

125. Ibid.

126. Id. at 3. 
Reasonableness implies, on the one hand, levels high enough to permit a trader to survive sharp temporary fluctuations without being subjected to a demand for increased margins which he may be unable to meet. On the other hand, levels must not be so high as to hamper market liquidity or interfere with the important part small speculators play in accommodating hedges and stabilizing prices. The record of past futures regulation certainly indicates that the Department of Agriculture, if it had full power over margins, would not fix them above a reasonable level. However, to facilitate passage of such a provision by Congress, the Secretary's authority to set minimum margins should be limited. ${ }^{127}$ The precise level to which the Secretary might be restricted must necessarily be somewhat arbitrary. But experience under the $33 \mathrm{I} / 3 \%$ wheat and corn margins in 1947 indicates that such a maximum might properly be $40 \%$ of the futures contract price.

The provision in the Securities Exchange Act of 1934 investing the Federal Reserve Board with power to set margin requirements for stock transactions ${ }^{128}$ serves not only as a precedent for the suggested legislation but emphasizes the need for its passage. A substantial increase in stock margin requirements tends to cause speculators to shift from securities to the commodity markets, where low exchange-established margins have permitted vast expansion of speculative holdings. ${ }^{129}$ Hence coordinated restriction of speculation in both fields is highly desirable to carry out the credit control function of the Securities Exchange Act margin provision. ${ }^{130}$ The Secretary of Agriculture is probably in the best position to decide upon speculative futures margins on the basis of market information provided him by the CEA; in the execution of this function, however, close cooperation becween the Secretary and the Federal Reserve Board would be important.

The absence of federal margin requirements has to a large extent been made a scapegoat for food and other commodity price increases. Actually,

127. Opponents of futures margin legislation repeatedly argue that unlimited discretion to set margins up to $100 \%$ of the contract price would give federal officers the power to destroy the exchanges. See, e.g., id. at 33. Since the valid purpose of such legislation can be accomplished by limiting margins to a far lower percentage than $100 \%$, it is probably advisable to eliminate this argument by setting a lid on the Secretary's marginfixing power.

128. Section 7, 48 STAT. 886 (1934), 15 U.S.C. $\$ 78 g$ (1946).

Securities margins are closely analogous to margin deposits in futures transactions since both protect the broker against customer default in case of adverse price change. A slight difference arises, however, from the fact that futures are simply agreements to buy or sell in the future, while shares of stock may immediately be used as collateral. Stock margins thus constitute part payment for a valuable chose in action, while futures margins are essentially merely a guarantee that the contract obligation will be performed. See Hearings, supra note 20, at 53-4.

129. REP. CEA 2 (1947); Hearings, supra note 20, at 20.

130. One purpose of $\$ 7$ of the Securities Exchange Act of 1934 was to prevent abnormal absorption of credit by speculation. H.R. REP. No. 1383, 73d Cong., $2 \mathrm{~d}$ Sess. 8 (1934) ; Sen. Rep. No. 792, 73d Cong., 2d Sess. 3 (1934). See Legis., Delegation of Power Under the Sectrities Exchange Act of 1934, 36 Cor. L. Rev. 974,984 (1936). 
these are chiefly the product of inflationary conditions connected with the present national emergency and crop outlook. ${ }^{131}$ Price trends in 1947-1948 under the $33 \mathrm{r} / 3 \%$ margins clearly indicate that increased margin requirements will not nullify the effects of these fundamental supply and demand factors. ${ }^{132}$ Efforts to control prices should therefore be aimed directly at these underlying factors, while margin controls should be restricted to their proper function of reducing price fluctuations which do not reflect basic market conditions. ${ }^{133}$

Summary. The imposition of higher margin requirements, as well as any further reduction of trading limits, will undoubtedly reduce the volume of exchange trading. It thus becomes important to assure that the proper functions of speculation-hedge facilitation and price stabilization-are left unhampered.

Speculation now constitutes approximately $75 \%$ of all futures transactions in the major commodities. ${ }^{134}$ The Department of Agriculture has maintained

131. 96 Cong. Rec. 11949-50 (Aug. 3, 1950). See notes 1 and 2 supra.

132. Hearings, supra note 20, at 105.

133. Speaking at Michigan State College on August 22, 1950, Secretary of Agriculture Brannan conceded that federal regulation of margins would not block commodity price inflation by itself. N.Y. Times, Aug. 25, 1950, p. 43, col. 7. And Rep. Cooley, in the congressional debate on the Defense Production Act of 1950, asserted categorically that "the price fluctuations which have taken place have occurred not as a result of this emergency situation or of speculation, but as the result of the natural play of the laws of supply and demand, as indicated by the Department of Agriculture Crop Reports." 96 Cong. Rec. 11950 (Aug. 3, 1950). For a table prepared by the CEA showing that the increase in trading in various commodity futures after the outbreak of the Korean fighting does not correspond directly to the increase in the price of these commodities, see 96 Cong. Rec. 11950 (Aug. 3, 1950). But cf. the view expressed by Rep. Buchanan that margin controls should be imposed so as to preclude the necessity for establishing commodity price ceilings. 96 Cong. Rec. 12405-6 (Aug. 10, 1950). See also note 2 supra.

134. The following table shows the open commitments of reporting and non-reporting traders (see note 82 supra) on all contract markets, averaging semi-monthly figures, for the fiscal year 1950. Separation of trades into hedging and speculative transactions is available only for reporting traders, but these traders generally account for virtually all hedges. REP. CEA 25 (1950). The proportion of speculative to hedging commitments shown below is somewhat lower than would be revealed by analysis of trading voltmte, since the open commitment figures do not indicate the speculative transactions of in-and-out traders and scalpers. Id. at 24.

\begin{tabular}{|c|c|c|c|c|c|c|c|c|}
\hline \multirow{3}{*}{ Class } & \multicolumn{2}{|c|}{ Wheat } & \multicolumn{2}{|c|}{ Corn } & \multicolumn{2}{|c|}{ Soybeans } & \multicolumn{2}{|c|}{ Cotton } \\
\hline & Long & Short & Long & Short & Long & Short & Long & Short \\
\hline & \multicolumn{4}{|c|}{ Percentage of tota } & \multicolumn{4}{|c|}{ open commitments } \\
\hline $\begin{array}{l}\text { Reporting traders: } \\
\text { Speculative } \ldots . \\
\text { Hedging } \quad . . .\end{array}$ & $\begin{array}{l}32.4 \\
20.8\end{array}$ & $\begin{array}{l}19.0 \\
39.9\end{array}$ & $\begin{array}{r}31.9 \\
9.6\end{array}$ & $\begin{array}{l}22.9 .9 \\
39.1\end{array}$ & $\begin{array}{l}30.4 \\
11.6\end{array}$ & $\begin{array}{l}21.2 \\
32.1\end{array}$ & $\begin{array}{l}20.8 \\
23.8\end{array}$ & $\begin{array}{l}16.8 \\
26.1\end{array}$ \\
\hline $\begin{array}{l}\text { Total large traders } \\
\text { Non-reporting traders }\end{array}$ & $\begin{array}{l}53.2 \\
46.8\end{array}$ & $\begin{array}{l}58.9 \\
41.1\end{array}$ & $\begin{array}{l}41.5 \\
58.5\end{array}$ & $\begin{array}{l}62.0 \\
38.0\end{array}$ & $\begin{array}{l}42.0 \\
58.0\end{array}$ & $\begin{array}{l}53.3 \\
46.7\end{array}$ & $\begin{array}{l}44.6 \\
55.4\end{array}$ & $\begin{array}{l}42.9 \\
57.1\end{array}$ \\
\hline Total open contracts & 100.0 & 100.0 & 100.0 & 100.0 & 100.0 & 100.0 & 100.0 & 100.0 \\
\hline
\end{tabular}

Id. at 26-7. 
that this preponderance of speculative over hedging transaction is unnecessary to provide sufficient liquidity for successful hedging. ${ }^{135}$ Available statistics appear to support this contention. In two successive years of wheat trading on the Chicago Board of Trade, the daily average number of reported open hedging contracts remained virtually identical while the total volume of trading, including speculation, declined by almost 50\%.136 This indicates that market liquidity can be sharply curtailed without apparent interference with hedging operations. Moreover, the Department of Agriculture has received no indication that a reduction of trading by approximately $45 \%$, resulting from a sharp increase in margin requirements in the fall of 1947, hampered hedging operations. ${ }^{137}$ In the absence of further information as to hedging needs and practices it is impossible to determine conclusively the volume of speculation necessary to support hedging. But the present speculation-hedging ratio, upwards of $8: 2$, is certainly greater than necessary to meet hedging requirements.

Nor is it likely that the price stabilization function of speculation would be hindered by a limited reduction in trading volume. As in the case of hedgefacilitation, the exact relationship between the volume of speculation and its effective stabilizing influence cannot be readily ascertained. However, statistics indicate that years of high trading volume have occasionally been characterized by greater price fluctuations than some leaner years. ${ }^{138}$ And reduction of the volume and magnitude of very large traders' activities actually promotes price stability. Moreover, the restriction of trading volume which the imposition of higher margins would entail is aimed directly at reducing unnecessary price

135. N.Y. Times, Oct. 1, 1947, p. 43, col. 5.

136. The relevant volume and open contract figures for these years, fiscal 1938 and 1939, are as follows:

Wheat Futures on the Chicago Board of Trade

\begin{tabular}{c|c|c|c}
\hline & $\begin{array}{c}\text { Total Annual } \\
\text { Volume }\end{array}$ & $\begin{array}{c}\text { Average Daily } \\
\text { Open Oontracts }\end{array}$ & $\begin{array}{c}\text { Average Daily Open } \\
\text { Hedging Oontracts* }\end{array}$ \\
\cline { 1 - 2 } $1937-38$ & $\begin{array}{c}1,000 \text { bushels } \\
1938-39\end{array}$ & $\frac{1,000 \text { bushels }}{1,000 \text { bushels }}$ & $\frac{1}{59,452}$ \\
& $8,300,837$ & 97,975 & 59,700 \\
\hline
\end{tabular}

Compiled from Rep. CE Adarin. 4, 5, 8 (1938); Rep. CE Adarrs. 3, 6 (1939).

*Hedging figures are available only for reporting traders, i.e., those whose daily trades or net positions amount to 200,000 bushels or more. See note 82 supra. However, most hedgers fall into this category since the average hedge position far exceeds the 200,000 figure. See note 32 supra.

137. Communication to the Yare Law Journal from J.M. Mehl, CEA Administrator, dated March 13, 1951, in Yale Law Library.

138. P. Menl, Relationseit Between the Daily Price Change, Opening to Close, of the Doninant Corn Future and the Daily Voluate of Trading in Corn Futures on the Chicago Baord of Trade (1935), and a similar study made for wheat futures. 
fluctuations by eliminating inadequately financed accounts. Too large a decrease in the volume of trading of small speculators might impede the stabilizing influence characteristic of small traders, as well as their important part in providing the market liquidity necessary for hedging on the exchanges. The Department of Agriculture can, however, be expected to consider these factors and apply trading restrictions with discretion and restraint.

\section{ConcLusion}

Risks of price fluctuations inherent in the present commodity marketing system have given rise to the mechanism of futures trading as a means of shifting these risks to speculators. Farm legislation which has in effect set floors under the prices of many agricultural commodities, ${ }^{139}$ and recent price ceilings, ${ }^{140}$ have narrowed the range of such fluctuations. Although this can be expected to reduce the volume of futures trading, as was the case under price controls during World War II, ${ }^{141}$ exchange operations will continue to serve their functions within the new price limits.

139. See generally, Shepherd, Agricultural Price Control (1945) passim. See also Ment, The Future of the Futures Markets 7, 12 (1941).

Minimum farm prices are now maintained through the Government's authority to grant loans to farmers at $90 \%$ of the "parity" value of most commodities. 63 STAx. 1051 (1949), 7 U.S.C. $\$ 1441$ (Supp. 1950). For a detailed explanation and appraisal of "parity," see ShepHerd, Agricultural Price Analysis 191-220 (1947).

140. On Jan. 26, 1951, the Office of Price Stabilization established price ceilings for all commodities except (1) raw agricultural commodities (at all levels of trade) selling below parity, see note 139 supra, or (2) processed agricultural commodities at the farm level when sold below parity there. Processors and distributors of such processed commodities were, however, permitted to pass on the exact amount of any increase in their raw material costs. The order set maximum prices for all other commodities at the highest level at which each individual dealer and processor made sales during the period from Dec. 19, 1950, to Jan. 25, 1951. P-H REP. ON Business $\{2,000$ (1951).

The chaotic price pattern which resulted from these individualized ceilings severely hampered futures trading; the cotton exchanges suspended operations completely and wheat hedging became impossible. N.Y. Times, Feb. 11, 1951, § 3, p. 1, col. 8; id., Feb. 13, 1951 , p. 1, col. 2. This situation was relieved considerably on Feb. 12, when the OPS removed ceilings on wheat, corn, oats, and a number of other commodities selling below parity levels, as well as on sugar. N.Y. Times, Feb. 13, p. 1, col. 2. At the same time the OPS expedited trading in soybeans, soybean meal, coffee and cocoa by replacing the general price freeze on these commodities with specific dollars-and-cents ceilings. P-H Rep. on Business $\llbracket 2003$ (1951). An order of March 3 established a single ceiling price for each grade and staple of cotton, thus permitting reopening of the cotton exchanges. Wall Street Journal, March 17, 1951, p. 3, col. 1. And trading in wool and wool top futures was resumed on April 9 after similar ceilings were fixed for futures in these commodities. N.Y. Times, April 10, 1951, p. 42, col. 3.

141. Virtually all the major commodities in which futures trading is conducted were subject to OPA price ceilings during World War II. Exchange operations continued substantially as usual in a number of commodities whose prices remained below ceiling levels. But where prices reached these limits, trading declined sharply since hedging became 
Effective operation of the exchange mechanism has been greatly enhanced by the development of federal regulation and supervision. This control has reduced price-distorting influences, and has largely eliminated the sharp practices which once accompanied speculation. Some improvement in the regulatory machinery is still needed, however, to obtain full advantage of freely competitive exchange trading. Expansion of the concept of manipulation as used in the Commodity Exchange Act and authorization of a limited federal marginsetting power are the most significant of these recommended changes. In addition, control over trading and position limits should be shifted to the Secretary of Agriculture. With the adoption of these improvements, futures trading will be better able to serve its proper functions, while still further pruned of its disruptive effect on the nation's economy.

unnecessary and speculation unprofitable in the absence of price changes. Scarcity of deliverable supplies and Government restrictions on deliveries of some commodities constituted further impediments to futures trading and restulted in suspension of trading in corn, butter, and several other commodities. REP. Food DistrIbution AdMIINISTRATION 107-108 (1943). Futures transactions in most other commodities, however, continued throughout the war. While the volume of trading on the whole was below pre-war levels, activity in rye and barley actually increased considerably during the war. See CEA, Comrarodity Futures Statistics 7-9 (1947). 